\title{
18. The playful city: Citizens making the smart city
}

\author{
Michiel de Lange
}

\begin{abstract}
This chapter about playful urban planning argues that play and games can help foster smart citizenship. In recent years, many cities have embarked on what is termed smart-city policies, deploying ICT to optimize a variety of urban processes. Various authors have noted that these smart-city policies often leave little room for civic action and agency. This contribution proposes the notion of the 'playful city' as an alternative vision for leveraging the smartness of people in creating more livable and lively cities. Play, it is argued, should not be positioned as offering solutions to urban problems. Instead, play offers alternative narratives about the potential futures of city-making, and reinserts the 'political' into smart city-making.
\end{abstract}

Keywords: Smart city, playful city, city-making, smartness, civic engagement

How can play and games entice urban stakeholders to become involved in making their city? In the nineteenth century, urban design became a professionalized discipline in reaction to the new machine era, the explosive growth of cities, and an impoverished class of new citizens lacking adequate housing (Hall 1988). With the current wave of 'smart technologies' pervading the urban realm, we observe how, once again, the shifting technological conditions of urban life affect the ways cities are made and the role of citizens in such processes. Today, municipalities all over the world seize the omnipresence of digital technologies as an opportunity to make their city 'smart.' In the wake of creative city policies popularized in the late 1990s (Landry and Bianchini 1995; Florida 2004, 2012; Landry 2008), smart city agendas aim to improve services and livability through ICTs and

Glas, R., S. Lammes, M. de Lange, J. Raessens, and I. de Vries, eds. 2019. The Playful Citizen. Civic Engagement in a Mediatized Culture. Amsterdam: Amsterdam University Press. DOI: $10.5117 / 97894629845^{23} / \mathrm{CH} 18$ 
supporting infrastructures. Large technology companies, including IBM, CISCO, Siemens, Microsoft, Philips, General Electric, among others, are forming coalitions with municipalities and knowledge institutions in 'triple helix' smart city consortia. Among the problems that smart city policies seek to address are mobility, clean energy, water and food production and distribution, health, living standards, and public participation (Hollands 2008).

Smart city visions and discourses have received much criticism (e.g. Hemment and Townsend 2013; De Lange and De Waal 2013; Söderström, Paasche, and Klauser 2014; Vanolo 2014; Calzada and Cobo 2015; Hollands 2015). These criticisms can be broken down in three major strands. The first strand of criticism focuses on the ill-defined notion of 'smartness.' What does 'smart' actually mean? Who is supposed to be smart? How can digital technologies be used for a pedagogy of smart urban life? The second strand targets the technocratic solutionism of these visions and the lack of agency ascribed to 'smart citizens.' All too often, technology-centric smart city visions assume that there are easy technological fixes for complex urban problems. They fail to leverage citizen creativity and smartness in more participatory ways of city-making. The third strand critically questions underlying simplistic views of what cities are or should be. What makes a city? Do we want city life and the urban experience to be about control, efficiency and predictability, or do we also value serendipity, friction, and playfulness?

To address these shortcomings, a variety of alternative notions have been coined. Many of them stress inclusivity and citizen agency. Quite a few of these build on the notion of playfulness to seek people-centric alternatives to the tech-driven smart city. Terms coined include the 'playable city' (Nijholt 2016), the 'ludic city' (Feirreis 2007; Stevens 2007), the 'gameful city' (Alfrink 2015), and the 'playful city' (De Lange 2014, 2015; Sicart 2016). At stake in these notions is the question of how games and play can help foster a smarter civic engagement. In this chapter, I further develop the idea of the 'playful city' as an alternative imaginary for utilitarian smart city agendas. This chapter investigates how playful media technologies can help to engage citizens in playing with and testing future city scenarios, and how as a result this can make cities and citizens smarter. I claim that the playful city is a productive concept to help conceptualize truly smart cities. This claim rests on three interconnected arguments, each addressing one of the above-mentioned criticisms. As I have argued elsewhere (De Lange 2013, 2014, 2015), play and games can be used first to leverage citizen creativity (smartness). Second, games and play can help to organize engagement, create collectives and 
strengthen people's agency (citizen participation). Third, games and play can be used to experiment with possible urban futures that are much more solidly rooted in a fertile substratum of theorizing urban culture instead of technology-driven efficiency (cityness). The notion of the playful city addresses civic agency in relation to professional disciplines. It aims to develop a perspective on playful citizens and playful urban planners.

The structure of the chapter is as follows. In the next section, I juxtapose two approaches to citizen engagement in urban planning. This section serves to articulate the central concerns of my argument that deal with new technologies, civic participation, smartness, and cityness. Furthermore, it traces how playfulness slowly entered its way into city-making with the advent of creative city policies. Next, I take a look at some historical strands of conceptualizing city life in terms of play, in order to construct a more solid conceptualization of the 'playful city.' The section exposes five different playful city themes, each harboring a different kind of playful civic smartness. The section also zooms in on the notion of play. The chapter then turns to a concrete case study of Rezone the Game, a game about vacant urban spaces in which I have been involved as a researcher, in order to find out how play can engage citizens in co-creating their urban environment. In the conclusion, I suggest that the concept of play serves to account for shifts in city-making and urban design practices. It is proposed that the tripartite ontology of play as material object, rule-based algorithm, and situated action offers a fruitful perspective on the changing roles of various stakeholders in shaping the future of the media city.

What is at stake in this contribution is how people can become engaged in their urban environment and with urban issues through 'playful media technologies' (see Frissen et al. 2015). The early days of digital media technologies bred in many commentators a gigantic optimism about their creative and democratizing potential to involve non-professionals in areas of professional expertise. For example, speaking about the field of design Mieke Gerritzen and Geert Lovink programmatically declared that "everyone is a designer in the age of social media" (Gerritzen and Lovink 2010). Similarly, Chris Anderson in his book Makers: The new industrial revolution claimed that "we are all designers now" (Anderson 2012, 53). We can and should doubt whether this is truly the case. As is argued in several chapters in this volume, there are many problems with the assumption that new media fuel more egalitarian and participatory societies, the end of expert knowledge, and a blossoming of high quality user generated content. There is little doubt, however, that digital media technologies profoundly shape new practices of city-making. 'Civic media' or 'civic technology' are terms that 
have recently gained considerable traction to designate the potential of media technologies to foster civic engagement (Gordon and Mihailidis 2016). ${ }^{1}$ The challenges of dealing with digital media technologies and citizen-driven city-making in the field of urban planning have become more urgent in the light of accelerating urbanization, a worldwide financial crisis that hit the sector particularly hard, and the rise of a DIY (do-it-yourself) maker culture. Like many other disciplines, urban design is faced with a tilting balance between professionals and amateurs, a decline in legitimacy of expert knowledge, and the rise of networked collective or 'connective' action (Varnelis 2008; Bennett and Segerberg 2012). This contribution argues that playful technologies and the ludification of (urban) culture (Raessens 2006, 2014) provide momentum and opportunity to productively address such questions of citizen engagement in city-making.

\section{Planning cities}

Citizen participation is by no means a new phenomenon in urban planning. In the 1970s, architects and planners already experimented with engaging communities in 'placemaking' and collective ownership through participatory design techniques (e.g. Landry 2008, 208). Only one century before, the inverse had happened in western societies, when a major professionalization took place in how cities were made (Hall 1988). In reaction to the industrialization of the city and the squalid living circumstances of a pauperized class of new urbanites, urban planning became a professional and academic discipline. Ever since, urban planning has been concerned with realizing visions of a better future. Dreams of a better tomorrow were frequently driven by fears and anxieties about city life today (Andraos et al. 2009). Urban design produced spaces that prescribed how people should behave. It was assumed, for instance, that the creation of healthier, greener, cleaner, and more aesthetically pleasing urban environments would lead to more societal stability (Huxley 2006, 774). Thus, planning became an instrument for superimposing order and control. The design of these 'governable spaces' would discipline and rationalize the minds and bodies of people, instill higher moral standards in them, and mold them into good citizens (Huxley 2006; Watson 2009). Central to the late Peter Hall's magnum opus Cities of tomorrow: An intellectual history of urban planning

1 Also see, for instance, reports by the Knight Foundation (2013) or various programs by UK-based Future Cities Catapult (2018). 
and design in the twentieth century (Hall 1988) is this continual struggle between planners who want to impose a top-down totalitarian planning logic onto the populace in the belief that a better society is never designed by committee, and those who take an on the ground perspective of people's everyday needs and desires, and wish to empower them. Best exemplifying these extremes in city-making is the often-recounted antagonism between New York City's modernist municipal planner Robert Moses and urban activist Jane Jacobs. Moses built bridges that were deliberately too low for public transportation, thus preventing racial minorities and low-income groups without private cars to get to Long Island Jones Beach (Winner 1980). Jacobs, on the other hand, made passionate pleas for messiness and diversity (Jacobs 1961/1992). As an activist, she took it to the streets and defended Greenwich Village against Moses' demolition plans to make space for a highway. In the humanities, a similar opposition is expressed in Michel de Certeau's well-known juxtaposition of a birds-eye city view from high above, and a city walker perspective at street-level (de Certeau 1984). We briefly look at how the Situationist art movement addressed this tension later on.

An apparent break from old ideals of urban planning as instruments for superimposing social order took place in the second half of the 199os with the rise of the 'creative city' paradigm. Building explicitly upon the legacy of Jane Jacobs, creative city proponents valued city life for being pleasantly chaotic, unpredictable, emergent, and self-organizing. Chaos is not to be curbed but cherished. In fact, in moderate doses it is a necessary precondition for creativity to blossom, via serendipitous encounters and exchanges. In the new paradigm, socio-economic prosperity of cities goes hand-in-hand with fostering their playful qualities. Cities with many playful 'third spaces' provide nurture beds for creativity and, ultimately, monetary revenue. Neither private domestic spaces nor utilitarian work spaces for rationalized productivity, these playful civic spaces were hotbeds for new ideas to blossom and come to fruition (Oldenburg 1989; Rifkin 200o; Thrift 2008). Creative city discourses fit very well with the rise of the information economy and the rhetoric of disruptive innovation.

Several points in the discussion above are relevant for this chapter. The first point is about 'smartness' in civic participation. The recurrent tension between city-making for the people and city-making by the people reflects opposing views of citizenship and participation. One involves a liberal view that highlights 'passive' individual rights ("the right to have rights"), while the other entails a republican communitarian view that emphasizes 'active' collective participation and civic duty (Somers 2008, 5, 14). Today's technology-driven smart cities seem to recombine these two types into a 
new type of participatory liberal citizenship, while at the same time stripping away their respective empowering potential and political agency. In many smart city visions, the good citizen is no longer a collectively organized and vocal political agent, or somebody protected by individual rights, but primarily a mute collector of data. Civic participation equals producing economic value. Although this is often touted to exemplify a new branch of participatory and entrepreneurial urban citizenship predicated upon a collectivized 'sharing economy' (Davidson and Infranca 2016), in terms of political agency it is very limited. No longer communal duty or individual rights, citizenship becomes individualized duty. You shall be a productive citizen. How then, can the notion of the playful city contribute to an active kind of 'smart' civic participation in which people can help shape the future of their cities?

The second point is about media technology and civic participation. When we think about smart cities, and indeed more generally about media and citizenship, we need to pay attention to the 'politics' of technologies and artifacts (Winner 1980). Technologies and their material and institutional arrangements may serve both as enabling devices and as instruments of control. Smart city technologies do not bring equal civic participation for everyone. They can empower some while posing insurmountable thresholds for others, in terms of accessibility or literacy. Like Moses' NYC bridges half a century ago, the institutional arrangements that come with smart cities might lead to social sorting and a splintering of urban public life (see Graham and Marvin 2001). So, one may ask how can we think of a more inclusive kind of civic participation through the notion of the playful city?

The third point is about what is called 'cityness,' or what constitutes city life (for example, Brenner and Schmid 2015). The brief discussion above sensitizes us to the fact that every well-meant vision about better urban futures is infused with ideological assumptions about city life and the role of citizens. This rhetoric of change conceals a deep core of what should remain stable. In the case of the industrial city, urban planning professed to bring positive change to the housing conditions of the masses and endow people with individual citizen rights to adequate living circumstances and-in many European cities - institutionalized welfare. The implication, however, was that the working class through a variety of new institutions were fixated and made controllable for the sake of the societal status quo. City life in the machine age was to be neat and orderly, and everything and everyone had to behave like a cog in it. Likewise, the smart city's emphasis on controlling and optimizing flows and environments through data means it perpetuates existing systems. It is, in a sense, a return to the modernist conception of 
the city as a controllable machine, or to be more precise, a smart cybernetic system controlled through feedback loops and self-learning capacities. The case of the smart city control center in Rio de Janeiro illustrates this drive toward centralized real-time control. The Rio Operations Centre was built by IBM and allows the municipality to gather data from 30 different agencies, display them on screens in a room-size 'urban dashboard,' and remotely manage processes like natural disasters or big public events (Townsend 2013, 65; Mattern 2015). The critical question then is what remains fixated through the rhetoric of smart urban change? To what extent do attempts at optimizing existing systems allow us to step outside of the box and conceive of radically new alternative visions for the future of cities? As I will argue in more detail below, I propose that the playful city imaginary is not only a productive notion to conceive of a more participatory smart citizenship, but also acts as a meta-reflective notion that opens up the space to critically question its own foundations.

\section{Playful cities in a historical context ${ }^{2}$}

In order to better understand how playful technologies can help engage people in participatory city-making, let us trace several historical themes in understanding the city as playful. Indeed, play and games have been part and parcel of city life (Stevens 2007). I identify five major playful city themes: the city as a center of entertainment; the city as everyday theater; the city as civic learning space; the city as a subversive playground; and urban simulation. First, from Roman bread and games (panem et circenses) to the present 'experience economy' (Pine and Gilmore 1999), cities have long been conceived as centers of entertainment and fun experiences. According to this view, the city is a locus for genuine playful behavior and activities, and for enjoying games or other forms of entertainment in designated settings. Second, with the rise of the modern metropolis, people's interactions in newly conceived public spaces came to be understood in theatrical metaphors. Theorists like Georg Simmel, Erving Goffman, and Lyn Lofland argued that urbanites in public situations engage in role-playing and information games using various props as a way to deal with life among strangers in highly segmented roles and situations (Goffman 1959; Lofland 1973; Simmel 1997). In this view, city life itself is conducive to everyday role-playing. Third, a historical strand of 'ludic architecture' connects play and games to the 
physical design of cities. In the Netherlands after the second World War, Dutch architect Aldo van Eyck dotted the ruined cityscapes with outdoor play spaces as a way to counter top-down functionalist planning policies and to open up room for people's own creativity (Oudenampsen 2013). Play served the pedagogical goal of teaching new generations to deal with conflict and tensions without resorting to destructive violence. Besides, what better way to make traumatized people smile again than watching children playing? According to this view, play spawns learning and Bildung ideals of civilization. Accompanying the restoration of the physical urbs, play mends the social bonds of civitas. A related fourth historical strand takes play as downright subversive. The artistic movement of The Situationists International criticized mass consumer society and sought to reclaim the right to the city through subversive counter-play and everyday spatial tactics, like dérive and detournement (drift and diversion) (Debord 1955, 1958, 2005; de Certeau 1984). A friend of Van Eijck, Constant Nieuwenhuys's New Babylon was an attempt to imagine a non-conformist city of play in which ever-changing environments would foster citizen creativity and engagement (Nieuwenhuys 1974; De Mul 2009). More recently, several studies in the same tradition focus on subcultural or countercultural urban practices like skateboarding or parkours (Borden 2001; Mould 2009). In this view, play is an everyday tactic to counter dominant structures by reclaiming agency and 'the right to the city' (Lefebvre 1996; Mitchell 2003). Fifth, while not strictly playful, terms from the world of informatics like networks, simulation, feedback, algorithms, and virtuality have come to profoundly influence architectural theory and practice as new ways to imagine, represent and design cities with digital tools (see Wigley 2001; Picon 2008). Cybernetics and systems theory have been very influential in understanding the city as emergent rule-based systems, which can be simulated and 'played' through creative recombinations and generative, algorithmic, responsive, or parametric design (see Berry 1964; Beesley and Khan 2009; Tan 2014).

What we can take from this, first, is a more nuanced and plural understanding of the notion of 'smart.' In the views above there is fairly clear conception of 'smartness' at play, each different from the other. Smartness in everyday role-playing means being clever, persuasive and having selfconfidence. In the case of Van Eyck's urban playgrounds smartness is didactic and self-empowering. The smart playful tactics of the Situationists evoke shrewdness and unorthodox associative thinking. And the smartness in urban simulations is of an almost demiurgic ambition as it attempts to confer sentience or intelligence to systems to aid in problem-solving and learning. As for the 'entertainment city', it may be a bit more difficult to 
discern smartness among those seeking a temporary carnivalesque inverse of normalcy (indeed it is easy to dismiss this as childish, stupefying, or opium for the masses). Yet, many of these urban play activities simultaneously aid in developing problem solving skills and fostering communal and situated experiences (not to mention that it takes creativity and originality to produce or curate such engaging experiences). There is a whole genre of mobile urban games with labels like pervasive/ubiquitous/location-based mobile/hybrid reality/alternate reality/urban games that frame the city as a playing board and escape the confines of the screen to be played in hybrid space (Chang and Goodman 2006; Montola, Stenros, and Waern 2009; de Souza e Silva and Hjorth 2009; de Souza e Silva and Sutko 2008, 2009). Hence, the 'playful city' complements the majority of smart city visions that equate 'smart' with automation and efficiency. It also vastly broadens our perspective of what 'smart citizenship' in relation to urban life could be.

A second point, made by many already, is that the modern separation of play and everyday life is not the default but the exception (see Ehrmann, Lewis, and Lewis 1968). Clearly, Van Eijck, Constant, Débord, and others, felt the need to go against the dominant mode of thinking with their integrated views. Recently, play and everyday life are (again) being understood as inextricably intertwined (Raessens 2006, 2014). This is largely driven by the pervasive presence of digital technologies in the urban realm, by the creative city agenda, and by the current search for smart city alternatives. It is imperative therefore that we consider playfulness not as some exotic idealistic notion far removed from the nitty-gritty of city-making, but as an inherent part of it. In fact, urban designers are turning to play to develop more diversified and resilient modes of urban planning (see Venhuizen 2011; Holleman, de Kort, and Lindemann 2012; Tan 2014).

A third point is that we must pay closer attention to the myriad of understandings of play and games. Conceptual clarity is needed to push the playful city as a productive idea to explore participatory smart citymaking. Although there is infinitely more to say about play and games, for sake of brevity, I shall stick to the well-known conceptualization of French sociologist and philosopher Roger Caillois. Caillois identified four types of play: competition (agôn), chance (alea), make belief (mimicry), and sensory delusion (ilinx) (Caillois 1958/2001). He further differentiated between two opposing poles in play attitudes: spontaneous and intrinsically motivated free play (paidia) versus rule-based and goal-oriented gaming (ludus). While other play theorists have better situated play in everyday reality (for instance Ehrmann, Lewis, and Lewis 1968; Sutton-Smith 1997), Caillois offers a powerful scheme to analyze how since the rise of the modern city, play 
in various guises has been a central element in imagining urban culture. ${ }^{3}$ More importantly for our purposes here, however, is that this scheme allows us to analyze and theorize playful city-making with more rigor.

Caillois' distinction between paidia and ludus, I argue, coincides with two stances toward the citizen engagement in the smart city. This helps us to better articulate the differences between the smart city and the playful city when it comes to citizen engagement. Citizen engagement in the majority of technology-driven smart city agendas tends toward the ludus pole: it is contractual and rule-governed, goal-oriented, and favors rationalized efficiency. ${ }^{4}$ The playful city serves to emphasize the paidia pole: free spontaneous play, not so much instrumental and goal-oriented but autotelic, that is, the joy of the activity in itself constitutes the major reason for engaging. Furthermore, smart city initiatives tend to use technologies (including games) in a very ludus-like way. Tech is understood as goal-oriented: it aims at solving problems and thus ending the engagement. I want to make a plea here for playful smart city interventions that instead lean toward the paidia pole: aimed at continuing engagement and self-motivated action. As we will see below, such playful interventions do not necessarily use games with the aim of solving a problem, but to ask questions about the underlying mechanisms and to create the conditions for people to come up with smart ideas. ${ }^{5}$ Additionally, Caillois' fourfold game typology allows us to establish that smart city interventions are mostly of the competitive agôn type. Complex urban problems like sustainability, crime, or congestion are agonistically framed as 'challenges' that can be solved via data and apps. As a city-branding strategy, smart cities are continually competing with each other in a host of global rankings. According to this view, smartness

3 Agôn underlies the 'ecological' views of the Chicago School that took urban life as a competition for scarce resources, and the post-industrial city engaged in competition with other cities vying for the attention of the creative industries. Alea connects to common views of urban life as serendipitous and is present in terms used to describe high or late modernity as a 'risk society' (Beck 1992) or in terms of radical uncertainty. Mimicry informs the view of urban life as constant theatrical role-playing. And ilinx can be recognized for example in the flaneur who loses himself in the crowd, Walter Benjamin's shock experiences brought about by visual media, Simmel's metropolitan blasé attitude caused by 'intensification of nervous stimulation,' and the Situationist legacy of psycho-geography.

4 One only needs to take a look at some of the corporate videos made by IBM Industries (2013) to understand that the rhetoric about citizen engagement is skin deep and only serves the functional needs of the municipality and corporate stakeholders.

5 See for instance Games for Cities (2018), a database that contains a mix of goal-oriented games and more playful interventions, several of them developed in the context of smart city policies. 
is of a competitive nature: it means 'outsmarting' the system, other people, or other cities. Competitive problem-solving is in my view a very narrow understanding of 'smart.' By contrast, I argue for playful city interventions that involve a broad range of game types, including alea, mimicry, and ilinx, to nurture and leverage different kinds of civic smartness. That could mean embracing and anticipating aleatory radical uncertainty, engaging in creative and cooperative make-belief, or seeking pleasurable experiences and deeply valuable "occasions of pure waste" (Caillois 1958/2001, 5) or "meaningful inefficiencies," as Gordon and Walter write in Chapter 16 of this volume.

\section{Rezone the Game: Playing against vacancy}

Armed with these directions and insights, I want to move from these theoretical and historical explorations of the playful city to a more concrete case, in order to see how participatory smart citizenship may work in practice. Rezone the Game is a project to help address the complex urban issue of vacancy. ${ }^{6}$ Two cultural organizations from Den Bosch in the Netherlands, the Bosch Architecture Initiative and art organization Wave of Tomorrow, collaborated with a game design school to create Rezone the Game (www. rezone.eu), challenging players to 'fight blight.' In the game, players work together to keep the city safe from deterioration by salvaging real estate from decline. There are four player roles: the proprietor (owner of the real estate), mayor (representing the municipality), engineer (urban designer), and citizen (neighbors). Rezone the Game is composed of a physical board game with a number of $3 \mathrm{D}$ printed iconic buildings that represent the neighborhood, an augmented reality layer of real-time information about these buildings projected on a screen, and a computer algorithm programmed to let buildings descend into vacancy like a wildfire. A camera above registers the players' moves by scanning $\mathrm{QR}$ codes on pawns. The game engine continually adapts to changes. To beat the system players must strategically collaborate instead of pursuing self-interests. The game was tested during a series of events including The Playful Arts Festival (2013) and Rezone Playful Interventions (2014), with the mayor of Den Bosch participating in playing. The large Dutch construction company Heijmans became interested. Their involvement initiated a new collaboration and lead to a follow-up game concept. Part of the motivation for the development of Rezone the Game was that it is hard to address complex questions like vacancy through conventional means.

6 I have been involved in this project as a paid advisor and researcher. 
Traditional parties involved in urban development are not inclined to invest in initiatives with uncertain outcomes and often wait for others to take the first step. It was believed that in a game stakeholders would feel freer to experiment without immediate (financial) consequences.

Again, this informs the three elements of smartness, civic participation, and cityness mentioned at the start of this chapter. First, in this case playful smartness is fostered on multiple levels. Players have to manage their different stakeholder roles, they must forge coalitions with other players and quickly negotiate, they must unpack the underlying mechanisms of vacancy, and think of ways to address this issue. Rezone the Game involves all of Caillois' play types: competition, role-playing, chance, and even dizzyingly speedy interactions with the computer system. The competitive element exists not between players but between players and the system. Playing together forges trust and connections between players. Real world stakeholders can meet each other in a playful atmosphere instead of at the negotiation table. The game is fun and acts as a catalyst for ensuing discussions and reflections among players (a crucial part of the play sessions), and even potential follow-ups. It is a deliberately simplified and artificial safe setting where real emotions and desires emerge. It invites people to temporarily stand in their adversaries' shoes. This could lead to better understanding of each other's standpoints through embodied experience and affects, instead of mere argumentation and deliberation. No longer passive as users of the city, players temporarily become smart planners.

Second, Rezone the Game helps to foster citizen engagement around the issue of vacancy. The game was used to invite real world stakeholders to the table. This happened during special play sessions and events such as The Playful Arts Festival (2013) and the Rezone Playful Interventions event (2014). Stakeholders met in a joyous atmosphere instead of tense town hall meetings or around the negotiation table. Playing together allowed relationships to form based on trust. Importantly, Rezone the Game is not a 'solutionist' attempt to solve a complex urban problem via technology. Playing the game helps people to become incentivized and take ownership for an otherwise abstract issue like vacancy. Playing makes the issue tangible via personal lived experiences and provides possible horizons for further action. The game mechanics and dynamics are deliberately aimed at stimulating social interactions and experimentation through collective action. Hence, we can conclude that this playful intervention strengthens a new hybrid liberal/ communal type of citizenship: people's individual rights to the city are extended to include a collective right to the smart city. 
Third, Rezone the Game represents a particular take on the notion of cityness. A superficial reading might suggest that it is a game that helps to solve the issue of vacancy. The underlying notion of cityness in such a view, would be one of a playable system with citizens as productive problem-solvers. According to this view, a complex urban problem can have an optimal solution, which leads the city into a state of equilibrium. By contrast, I understand the game to actually have a deeper narrative, which tells that urban issues like vacancy are far too complex to model, let alone solve, by simple technological means. ${ }^{7}$ Previously, I suggested that the special quality of playful city interventions like Rezone the Game is that they act on a meta-level. Gregory Bateson famously theorized that play always consists of a level of meta-communication. When monkeys in the zoo engage in play-fighting, they exchange signals that communicate that what they are doing is not fighting. In his words, we face "two peculiarities of play: $(a)$ that the messages or signals exchanged in play are in a certain sense untrue or not meant; and $(b)$ that that which is denoted by these signals is nonexistent" (Bateson 1972/1987, 141). In my view, this is precisely the strength of playful city interventions like Rezone the Game: it questions its own solutionist promise by overtly signaling to not actually do what it purports to do (solving vacancy). Instead, the game impels players to stake claims about what kind of city they actually want, to negotiate the underlying issue, and to agree on how to address it collectively. This involves a view of the city as a commons, a space of perpetual tension and conflict and at the same time a space that allows for negotiation and collaboration (Foster and Iaione 2016, 288).

As I have argued above, understanding city life in terms of play and games has a long tradition. Arguably, this connection has become even more important today. For an increasing number of people playing games is part of their cultural repertoire. They have grown up playing video games and are 'ludo-literate' (see Part I of this volume). Moreover, as outlined in the Introduction and in earlier work, we live in a playful media culture (Frissen et al. 2015). We are continuously surrounded by a plethora of technologies that offer spaces for playful experimentation, and shape our understanding of the world as playful. Playing means acquiring knowledge about the world and the capacity to act in it, in what can be called 'ludo-epistemology' (see Part II of this volume). Therefore, it no longer seems strange to have various organizations turn to games to address serious issues.

7 See also the notion of 'procedural rhetoric,' which designates how arguments can be created and unpacked using computer models, thus making claims about how things work (Bogost 2007, $1-64 ; 2011,13-14)$. 


\section{Reflection and discussion}

This chapter dealt with the question of how play and games can help foster a smarter civic engagement. The current challenge of making our cities smart impels us to ask not just what is technically feasible or economically viable, but what is also socially desirable. Do we want smart tech programmed by companies to make decisions for us? Or do we want to include the 'smartness' of actual people? Do we want efficient cities, or also generate other values like sustainability, democratic legitimacy, playfulness, and a sense of ownership? Do we consider technologies as just utilitarian solutions, or far more broadly as part of our everyday culture and experiences? The notion of the playful city, I argue, helps to do this by conceptualizing 'smart cities' in terms of smartness, civic participation, and cityness. The playful city opens up a people-centric and plural perspective on 'smartness,' instead of just a technologically driven one. If we want citizens to be smart alongside cities, we need to better understand how people already possess the capacity to act smart in a multitude of ways and how we can leverage this to make better and more interesting cities. The playful city also helps to think about citizen participation. Play and games themselves are not solutions for urban problems. They do however change the ways we address complex urban issues through more inclusive, participatory (and also more 'messy') approaches. Play also provides a far richer outlook on cityness. Play highlights the importance of creativity, curiosity, and culture in city life.

Play redefines roles and relations between professionals and citizens in processes of making cities. It has become clear that the making of cities no longer is the exclusive domain of architects and planners. Rather, it is one of the domains shaping, and being shaped by, playful citizenship. Gamemakers, media artists, app developers, and a variety of other urban dwellers are becoming the designers of today's cities (De Lange 2015). Cities are facing ever more complex issues. This requires smart strategies to tap into the pool of citizen smartness and leverage civic participation. Games and play seem great ways to do so. However, this requires policy makers and planners to relinquish control, accept uncertain and ambiguous outcomes, and to allow the possibility of failure. Games are ontologically multifaceted: they are composed of a set of constitutive rules, a material setting, and actualized through the embodied activities of the players. This is comparable to what urban designers recognize as program, design and use, but with a twist. Game designers create rules and can influence the setting yet the game is only actualized in play. People playing are not merely end users. They are active participants. They frequently play with the (rules of) the game (see 
Chapter 11 by Glas and Lammes in this volume), discuss the issues raised in the game through the use of strong concepts (Schouten et al. 2016), or even question the very foundations of the game as we have seen above. According to Dutch cultural historian Johan Huizinga, author of the seminal Homo ludens, play is not just part of culture, but it is central to its origin (Huizinga 1955). Play generates culture because it provides room for innovation. Play offers a safe space for experiment and collaborations in which failing does not immediately have grave consequences. Huizinga's observation that culture (which he used in the narrow sense of 'civilization') emerges from play, suggests that playful interventions like the one discussed in this chapter may contribute to a new urban planning culture and participatory urban culture (Van Westrenen 2011; De Lange, Van Boxmeer, and Peters 2014). In addition to governments, corporations and (design) professionals, playful citizens are key in creating smart urban futures. If we are serious about making our cities smarter, we need to understand them as playful.

As already mentioned, the playful city also allows us to consider more critical issues. A first consideration involves the fine balance between persuasion and manipulation. Rezone the Game persuades people to address the issue of urban vacancy through collaboration, but it could easily become manipulative if outcomes are used by one party for their own profit. A closely related second consideration involves the exploitation of people's free efforts in what is known as 'playbor,' a portmanteau of play and labor (Kücklich 2005; Rheingold 2012, 134-135; Walz and Deterding 2015). Several authors argue that play in late capitalism has been absorbed by work itself through the conflation of labor and leisure time, and the concomitant self-disciplining ethics of the creative class (e.g. Rifkin 2000; Scholz 2013; Fortunati 2015). Play risks becoming absorbed in goal-oriented utilitarian practices, and neoliberal and self-disciplining discourses of labor as play. While this has not received much attention here, this should be born in mind when studying and designing the playful city. Quasiparticipation is a third consideration. Who can play, who may actually decide? What will happen to the outcomes of games like Rezone the Game? What suggestions are being made? To what extent should we consider games like these a kind of 'tokenism' if nothing really profound happens with them (Arnstein 1969)? A fourth critical question about 'civic media' is how a technology-driven participatory citizenship might reshuffle or even bypass legitimate democratic institutions (see Foster and Iaione 2016, 339). How desirable is it if civic tech only serves the interests of groups of people capable enough of making productive use of these technologies 
(for a discussion of public values in the 'platform society,' see Van Dijck, Poell, and De Waal 2018)?

For future research, I suggest that the playful cities agenda should be pushed along the following lines: 1) Research: What urban issues lend themselves to being addressed by play and games, and what are the key considerations? 2) Design: What type(s) of games, and which mechanicsdynamics-aesthetics, can be employed for particular complex urban issues? 3) Validation: How can we assess and validate the role of play and games in urban culture? 4) Governance: How can we up the scale and appropriately institutionalize the use of games for complex urban issues (i.e. stakeholder coalitions, toolkit, best practices)?

\section{References}

Alfrink, K. 2015. The gameful city. In The gameful world:Approaches, issues, applications, eds. S. P. Walz and S. Deterding, 527-56o. Cambridge, MA: The MIT Press.

Anderson, C. 2012. Makers: The new industrial revolution. New York: Crown Business.

Andraos, A., D. Wood, Y. Vobis, M. Alexander, H. Zaic, J. Esparza, A. Menke, S. Dufaux, J. L. Andersen, A. Maymind, and W. Boning. 2009. 49 cities. Storefront for Art and Architecture. http://www.storefrontnews.org.

Arnstein, S. R. 1969. A ladder of citizen participation. JAIP 35 (4): 216-224.

Bateson, G. 1972/1987. Steps to an ecology of mind: Collected essays in anthropology, psychiatry, evolution, and epistemology. San Francisco, CA: Chandler Publishing Co.

Beck, U. 1992. Risk society: Towards a new modernity. London: Sage Publications.

Beesley, P., and O. Khan. 2009. Responsive architecture/performing instruments. In Situated Technologies Pamphlet series, eds. O. Khan, T. Scholz, and M. Shepard. New York: The Architectural League of New York. http:// www.situatedtechnologies.net/files/ST4-ResponsiveArchitecture.pdf.

Bennett, W. L., and A. Segerberg. 2012. The logic of connective action: Digital media and the personalization of contentious politics. Information, Communication \& Society 15 (5): 739-768.

Berry, B. J. L. 1964. Cities as systems within systems of cities. Papers in Regional Science 13 (1): 147-163.

Bogost, I. 2007. Persuasive games: The expressive power of videogames. Cambridge, MA: The MIT Press. 
-. 2011. How to do things with videogames. Minneapolis, MN: University of Minnesota Press.

Borden, I. 2001. Skateboarding, space and the city: Architecture and the body. New York: Berg.

Brenner, N., and C. Schmid. 2015. Towards a new epistemology of the urban? City 19 (2-3): 151-182.

Caillois, R. 1958/2001. Man, play, and games. Trans. M. Barash. Chicago, IL: University of Illinois Press.

Calzada, I., and C. Cobo. 2015. Unplugging: Deconstructing the smart city. Journal of Urban Technology 22 (1): 23-43.

Chang, M., and E. Goodman. 20o6. Asphalt games: Enacting place through locative media. Leonardo Electronic Almanac 14 (3).

Davidson, N. M., and J. J. Infranca. 2016. The sharing economy as an urban phenomenon. Yale Law \& Policy Review 34 (2): 216-279.

de Certeau, M. 1984. The practice of everyday life. Berkeley, CA: University of California Press.

De Lange, M. 2009. The mobile city project and urban gaming. Second Nature: International journal of creative media 1 (2): 160-169.

- 2013. Rezone the Game: Playing for urban transformation. BIJT.org. http://www.bijt.org/wordpress/2013/04/24/rezone-the-game-playing -for-urban-transformation.

-. 2014. Playful planning: Citizens making the smart and social city. ECLECTIS report: A contribution from cultural and creative actors to citizens' empowerment. http://www.dedale.info/_objets/medias/autres/ publication-eclectis-corrigee101214-965.pdf.

-.2015. The playful city: Using play and games to foster citizen participation. In Social technologies and collective intelligence, ed. A. Skaržauskienė, 426-434. Vilnius: Mykolas Romeris University.

De Lange, M., R. van Boxmeer, and T. Peters, eds. 2014. Rezone playful interventions: Spelen voor de toekomst. Den Bosch: BAI \& bART/DW.

De Lange, M., and M. de Waal. 2013. Owning the city: New media and citizen engagement in urban design. First Monday 18 (11). http://firstmonday.org/ article/view/4954/3786.

De Mul, J. 2009. Database architecture: Anthropological reflections on the art of the possible. The Journal of Asian Arts \& Aesthetics 3:1-14.

de Souza e Silva, A., and L. Hjorth. 2009. Playful urban spaces a historical approach to mobile games. Simulation \& Gaming 40 (5): 602-625.

de Souza e Silva, A., and D. M. Sutko. 2008. Playing life and living play: How hybrid reality games reframe space, play, and the ordinary. Critical Studies in Media Communication 25 (5): 447-465. 
—. 2009. Digital cityscapes: Merging digital and urban playspaces. New York: Peter Lang.

Debord, G. 1955. Introduction to a critique of urban geography. Les Lèvres Nues 6. -.1958. Theory of the dérive. Internationale Situationiste 2.

- 2005. Society of the spectacle. London: Rebel Press.

Ehrmann, J., C. Lewis, and P. Lewis. 1968. Homo ludens revisited. Yale French Studies 41:31-57.

Feirreis, L. 2007. New Babylon reloaded: Learning from the ludic city. In Space time play: Computer games, architecture and urbanism: The next level, eds. F. Von Borries, S. P. Walz, and M. Boettger, 332-334. Boston, MA: Birkhauser Verlag AG.

Florida, R. L. 2004. The rise of the creative class: And how it's transforming work, leisure, community and everyday life. New York: Basic Books.

-. 2012. The rise of the creative class: Revisited. New York: Basic Books.

Fortunati, L. 2015. New media, play, and social identities. In Playful identities: The ludification of digital media cultures, eds. V. Frissen, S. Lammes, M. de Lange, J. de Mul, and J. Raessens, 293-305. Amsterdam: Amsterdam University Press.

Foster, S. R., and C. Iaione. 2016. The city as a commons. Yale Law \& Policy Review 34 (2): 280-349.

Frissen, V., S. Lammes, M. de Lange, J. de Mul, and J. Raessens, eds. 2015. Playful identities: The ludification of digital media cultures. Amsterdam: Amsterdam University Press.

Future Cities Catapult. 2018. Home: Future cities catapult. Future Cities Catapult. http://futurecities.catapult.org.uk.

Games for Cities. 2018. City-game database. Games for cities. http://gamesforcities.com/database.

Gerritzen, M., and G. Lovink, eds. 2010. Everyone is a designer in the age of social media. Amsterdam: BIS Publishers.

Goffman, E. 1959. The presentation of self in everyday life. Garden City, NY: Doubleday.

Gordon, E., and P. Mihailidis, eds. 2016. Civic media: Technology |Design $\mid$ Practice Cambridge, MA: The MIT Press.

Graham, S., and S. Marvin. 2001. Splintering urbanism: Networked infrastructures, technological mobilities and the urban condition. New York: Routledge.

Hall, P. 1988. Cities of tomorrow: An intellectual history of urban planning and design in the twentieth century. Oxford: Basil Blackwell.

Hemment, D., and A. Townsend, eds. 2013. Smart citizens. Manchester, UK: FutureEverything Publications. 
Hollands, R. G. 2008. Will the real smart city please stand up? Intelligent, progressive or entrepreneurial? City 12 (3): 303-320.

- 2015. Critical interventions into the corporate smart city. Cambridge Journal of Regions, Economy and Society 8 (1): 61-77.

Holleman, E., R.-J. de Kort, and S. Lindemann, eds. 2012. Balkan in de polder: Naar organische gebiedsontwikkeling in Nederland? Amsterdam: Mondriaanfonds.

Huizinga, J. 1955. Homo ludens: A study of the play-element in culture. Boston, MA: Beacon Press.

Huxley, M. 2006. Spatial rationalities: Order, environment, evolution and government. Social \& Cultural Geography 7 (5): 771-787.

IBM Industries. 2013. IBM Smarter Cities Intelligent Operations Center 1.6 Demo. Youtube. http://www.youtube.com/watch?v=3yVe1DL2qjs.

Jacobs, J. 1961/1992. The death and life of great American cities. New York: Vintage Books.

Knight Foundation. Knight foundation: Trends in civic tech. Knight Foundation. http://knightfoundation.org/features/civictech.

Kücklich, J. 2005. Precarious playbour: Modders and the digital games industry. The Fibreculture Journal 5. http://five.fibreculturejournal.org/ fcj-025-precarious-playbour-modders-and-the-digital-games-industry.

Landry, C. 2008. The creative city: A toolkit for urban innovators. London: Comedia.

Landry, C., and F. Bianchini. 1995. The creative city. London: Demos.

Lefebvre, H. 1996. Writings on cities. Trans. E. Kofman and E. Lebas. Cambridge, MA: Blackwell Publishers.

Lofland, L. H. 1973. A world of strangers: Order and action in urban public space. New York: Basic Books.

Mattern, S. 2015. Mission control: A history of the urban dashboard. Places Journal. http://placesjournal.org/article/mission-control -a-history-of-the-urban-dashboard.

Mitchell, D. 2003. The right to the city: Social justice and the fight for public space. New York: Guilford Press.

Montola, M., J. Stenros, and A. Waern. 2009. Pervasive games: Theory and design. Boston, MA: Morgan Kaufmann.

Mould, O. 2009. Parkour, the city, the event. Environment and Planning D: Society and Space 27 (4): 738-750.

Nieuwenhuys, C. 1974. New Babylon: A nomadic town. The Hague: Haags Gemeentemuseum. http://www.notbored.org/new-babylon.html.

Nijholt, A., ed. 2016. Playable cities: The city as a digital playground. London: Springer. 
Oldenburg, R. 1989. The great good place: Cafes, coffee shops, community centers, beauty parlors, general stores, bars, hangouts, and how they get you through the day. New York: Paragon House.

Oudenampsen, M. 2013. Aldo van Eyck and the city as playground. MO. http://merijnoudenampsen.org/2013/o3/27/aldo-van -eyck-and-the-city-as-playground.

Picon, A. 2008. Toward a city of events: Digital media and urbanity. New Geographies 0:32-43.

Pine, B. J., and J. H. Gilmore. 1999. The experience economy: Work is theatre \& every business a stage. Boston, MA: Harvard Business School Press.

Raessens, J. 2006. Playful identities, or the ludification of culture. Games and Culture 1 (1): 52-57.

- 2014. The ludification of culture. In Rethinking gamification, eds. M. Fuchs, S. Fizek, P. Ruffino, and N. Schrape, 91-114. Lüneburg: meson press.

Rheingold, H. 2012. Net smart: How to thrive online. Cambridge, MA: The MIT Press.

Rifkin, J. 2000. The age of access: The new culture of hypercapitalism, where all of life is a paid-for experience. New York: J. P. Tarcher/Putnam.

Scholz, T. 2013. Digital labor: The internet as playground and factory. New York: Routledge.

Schouten, B., G. Ferri, M. de Lange, and K. Millenaar. 2016. Games as strong concepts for city-making. In Playable cities: The city as a digital playground, ed. A. Nijholt, 23-45. London: Springer.

Sicart, M. 2016. Play and the city. Navigationen 16 (1): 25-40.

Simmel, G. 1997. The metropolis and mental life. In Simmel on culture: Selected writings, eds. D. Frisby and M. Featherstone, 174-185. London: Sage Publications.

Söderström, O., T. Paasche, and F. Klauser. 2014. Smart cities as corporate storytelling. City 18 (3): 307-320.

Somers, M. 2008. Genealogies of citizenship: Markets, statelessness, and the right to have rights. New York: Cambridge University Press.

Stevens, Q. 2007. The ludic city: Exploring the potential of public spaces. New York: Routledge.

Sutton-Smith, B. 1997. The ambiguity of play. Cambridge, MA: Harvard University Press.

Tan, E. 2014. Negotiation and design for the self-organizing city: Gaming as a method for urban design. Delft: Delft University of Technology, Faculty of Architecture and the Built Environment, Department of Urbanism.

Thrift, N. J. 2008. Non-representational theory: Space, politics, affect. New York: Routledge. 
Townsend, A. 2013. Smart cities: Big data, civic hackers, and the quest for a new utopia. New York: W. W. Norton \& Company.

Van Dijck, J., T. Poell, and M. de Waal. 2018. The platform society: Public values in a connective world. Oxford: Oxford University Press.

Vanolo, A. 2014. Smartmentality: The smart city as disciplinary strategy. Urban Studies 51 (5): 883-898.

Varnelis, K., ed. 2008. Networked publics. Cambridge, MA: The MIT Press.

Venhuizen, H., ed. 2011. Game urbanism: Manual for cultural spatial planning. Amsterdam: Valiz Book and Cultural Projects.

Walz, S. P., and S. Deterding. 2015. The gameful world: Approaches, issues, applications. Cambridge, MA: The MIT Press.

Watson, V. 2009. 'The planned city sweeps the poor away...: Urban planning and 21st century urbanisation. Progress in Planning 72 (3): 151-193.

Westrenen, F. van. 2011. Urbanism game. In Game urbanism: Manual for cultural spatial planning, ed. H. Venhuizen. Amsterdam: Valiz Book and Cultural Projects.

Wigley, M. 2001. Network fever. Grey Room 4:82-122.

Winner, L. 1980. Do artifacts have politics? Daedalus 109 (1): 121-136.

\section{About the author}

Michiel de Lange is Assistant Professor in New Media Studies, Department of Media and Culture Studies, Utrecht University. He is co-founder of The Mobile City, a platform for the study of new media and urbanism, an advisor on E-culture at Mediafonds, and works as a researcher in the field of (mobile) media, urban culture, identity, and play. He is a researcher in the NWO Creative Industries funded project The Hackable City, about the ways digital media shape the future of city-making. 